Article

\title{
Identifying Groundwater Fluoride Source in a Weathered Basement Aquifer in Central Malawi: Human Health and Policy Implications
}

\author{
Marc J. Addison ${ }^{1, *(1)}$, Michael O. Rivett ${ }^{1}$, Peaches Phiri ${ }^{2}$, Prince Mleta ${ }^{2}$, Emma Mblame ${ }^{2}$, \\ Modesta Banda ${ }^{2}$, Oliver Phiri ${ }^{3}$, Wilson Lakudzala ${ }^{3}$ and Robert M. Kalin ${ }^{1}$ (D) \\ 1 Department of Civil \& Environmental Engineering, University of Strathclyde, Glasgow G1 1XJ, UK; \\ michael.rivett@strath.ac.uk (M.O.R.); robert.kalin@strath.ac.uk (R.M.K.) \\ 2 The Ministry of Irrigation and Water Development, Lilongwe Headquarters, Private Bag 390, Lilongwe, \\ Malawi; peachesphiri@gmail.com (P.P.); princemleta@gmail.com (P.M.); emmambalame@gmail.com (E.M.); \\ modesta.banda@gmail.com (M.B.) \\ 3 BAWI Consultants, Private Bag 15, Likuni, Lilongwe, Malawi; oliverphiri0@gmail.com (O.P.); \\ wdzala@gmail.com (W.L.) \\ * Correspondence: marc.addison@strath.ac.uk
}

Received: 22 June 2020; Accepted: 18 July 2020; Published: 21 July 2020

\begin{abstract}
Consumption of groundwater containing fluoride exceeding World Health Organization (WHO) $1.5 \mathrm{mg} / \mathrm{L}$ standard leaves people vulnerable to fluorosis: a vulnerability not well characterised in Malawi. To evaluate geogenic fluoride source and concentration, groundwater fluoride and geology was documented in central Malawi where groundwater supplies are mainly sourced from the weathered basement aquifer. Lithological composition was shown as the main control on fluoride occurrence. Augen gneiss of granitic composition posed the greatest geological fluoride risk. The weathered basement aquifer profile was the main factor controlling fluoride distributions. These results and fluoride-lithology statistical analysis allowed the development of a graded map of geological fluoride risk. A direct link to human health risk (dental fluorosis) from geological fluoride was quantified to support science-led policy change for fluoride in rural drinking water in Malawi. Hazard quotient (HQ) values were calculated and assigned to specific water points, depending on user age group; in this case, $74 \%$ of children under six were shown to be vulnerable to dental fluorosis. Results are contrary to current standard for fluoride in Malawi groundwater of $6 \mathrm{mg} / \mathrm{L}$, highlighting the need for policy change. Detailed policy recommendations are presented based on the results of this study.
\end{abstract}

Keywords: fluoride; groundwater; Sustainable Development Goal 6; water quality; rural community water supply; weathered basement aquifer; hydrogeology; policy change

\section{Introduction}

The United Nations (UN)'s Joint Monitoring Programme (JMP) has classified fluoride as a Sustainable Development Goal 6 (SDG 6) chemical contaminant of concern for Water and Sanitation [1]. Whilst fluoride in small doses $(0.5-1.5 \mathrm{mg} / \mathrm{L})$ is beneficial, above this range the risks of worsening fluorosis conditions, dental-skeletal-crippling, increase [2]. Globally 200 million people may be at risk from fluoride consumption exceeding the $1.5 \mathrm{mg} / \mathrm{L}$ World Health Organization (WHO) standard [3,4]. During the Millennium Development Goal (MDG) period and continuing into the current SDG phase, community hand-pumped groundwater supplies have proliferated in low-income, developing countries. This has often occurred without systematic analysis of geo-hazards [5]. Research to investigate groundwater fluoride and associated health risks is required in such countries, including 
Malawi, where most rural communities fully rely on groundwater for their drinking-water supply [6]. Groundwater fluoride concentration data may often be sparse and assessment of health risks from natural, geogenic sources of fluoride is frequently non-existent. Science-based policy interventions to support the SDGs in such cases vitally require integrated consideration of geological, geographical, hydrochemical, and water-resource management factors together with risk analysis of human exposure to support regulatory control and provision of safe water supply.

Our recent review of groundwater fluoride in Malawi [7] confirms risks are much less well characterised than other fluoride 'hotspot' countries on the east African rift system (EARS), such as Kenya, Tanzania, and Ethiopia [7-11]. Systematic determination of fluoride risk has not occurred in this EARS periphery location and is despite some documented dental fluorosis in Malawi coinciding with increased groundwater fluoride [12-14]. Our interest in the Nathenje area, central Malawi was triggered by not only observations of dental fluorosis coinciding with somewhat elevated groundwater fluoride $(<0.5-7.0 \mathrm{mg} / \mathrm{L})[12,13]$, but also, our perception this fluoride occurrence appeared anomalous and perhaps unexpected given its plateau location removed from the main rift valley and a geological setting dominated by meta-sediments. Assessment of fluoride risk nationally requires such areas of less obvious risk (compared to say deep source hot springs) to be included. Factors controlling intermediate fluoride concentrations occurring mostly below the current (generous) Malawi drinking water standard of $6 \mathrm{mg} / \mathrm{L}$, may well exceed the current WHO $1.5 \mathrm{mg} / \mathrm{L}$ standard. This concern motivates our study of the chosen area to inform the national strategy.

The nature of the geology present is expected to be a critical factor. Groundwater fluoride arises from two main geogenic source types: deep sourced hydrothermal inputs and/or shallow rock weathering $[3,15,16]$. Hydrothermal systems may contain elevated groundwater fluoride, occasionally exceeding $1000 \mathrm{mg} / \mathrm{L}$ [3]. Weathering of shallow rocks also contributes where groundwater flows through units rich in fluoride-bearing minerals. Alkaline igneous rocks are an important source of such minerals and globally recognised as a dominant groundwater fluoride source $[2,17-19]$. Fluoride is preferentially weathered from amphiboles (hornblende) and micas (biotite and muscovite) into groundwater. Apatites containing substituted fluoride are more soluble and an important source [3]. Example cases are reported in India, Ghana, Sri Lanka, and the USA [2,3]. In Sri Lanka, for instance, elevated fluoride occurs where granitic or biotite gneiss lithologies dominate and the nature of the underlying basement rock is the controlling factor on concentrations, with deeper boreholes generally containing higher fluoride [15]. Fluoride concentrations in crystalline basement rocks generally span $<1$ to $10 \mathrm{mg} / \mathrm{L}$ and hence may or may not pose problems [3]. Overall, the preponderance of international evidence confirms significant geological control on groundwater fluoride occurrence. This relationship provides the basis for our geological-based methodology. Whilst anthropogenic sources of fluoride exist, including industrial $[20,21]$ and untreated sanitation [22] sources, these are currently insignificant in our rural study area and most of rural Malawi. Hence, an assumption of geological control on groundwater fluoride occurrence generally is reasonable.

Hence, our hypothesis is that the extent of fluoride occurrence in the weathered basement aquifers of Malawi is geologically controlled. Meaning, fluoride concentrations in groundwater predominantly reflect in-situ local geological composition. We test this hypothesis and investigate the link between fluoride occurrence and human health by integrating our results with health proxy indicators (dental fluorosis). Testing this hypothesis is pivotal to our overarching aim to provide an evidence-based framework that informs science-led policy review of groundwater fluoride risk management currently underway by the Government of Malawi, Ministry of Irrigation and Water Development (MoIWD). The ambition (and current Government planning strategy) is to mitigate risk to human health from groundwater fluoride by incrementally reducing the current Malawian drinking water standard for fluoride [23]. The framework to achieve this ambition is developed and demonstrated herein and comprises:

- Use of borehole water quality surveys to assess groundwater fluoride occurrence;

- Assessment of the hypothesised geological control on observed groundwater fluoride; 
- Use of Government of Malawi survey results to assess health risks via proxy dental fluorosis indicators;

- Integrating these lines of evidence to investigate linkages between groundwater fluoride and health and develop risk factors for water points.

The study is the first in Malawi to integrate groundwater fluoride occurrence data with fluorosis health effects attributed to groundwater supply and consumption. The concurrent analysis of water source risks, geological sources and review of policy is multi-faceted and represents a paradigm shift in Malawi's approach in assessing fluoride problems by critically assessing the linkage between groundwater fluoride occurrence, health effect risks and proxy manifestation.

\section{Study Area}

\subsection{Setting}

Malawi is situated at the southern periphery of the EARS (Figure 1). In central and northern Malawi, it features as a deep freshwater lake, Lake Malawi [24]. In southern Malawi, the valley floor is exposed at the surface as a series of sedimentary basins [7]. The traditional authority (TA) Mazengera study area is in the district of Lilongwe, central Malawi (Figure 1). It lies on the eastern edge of the Kasungu-Lilongwe Plain, an elevated plateau composed of Lower Palaeozoic-Precambrian basement rock and colluvium of around $6000 \mathrm{~km}^{2}$ with elevations varying from 1000-1800 m above sea-level (masl). Drainage in the study area generally flows northwest from the Nkhoma and Chilenje hills towards the Lilongwe River, and southeast towards the Linthipe River (Figure 1).

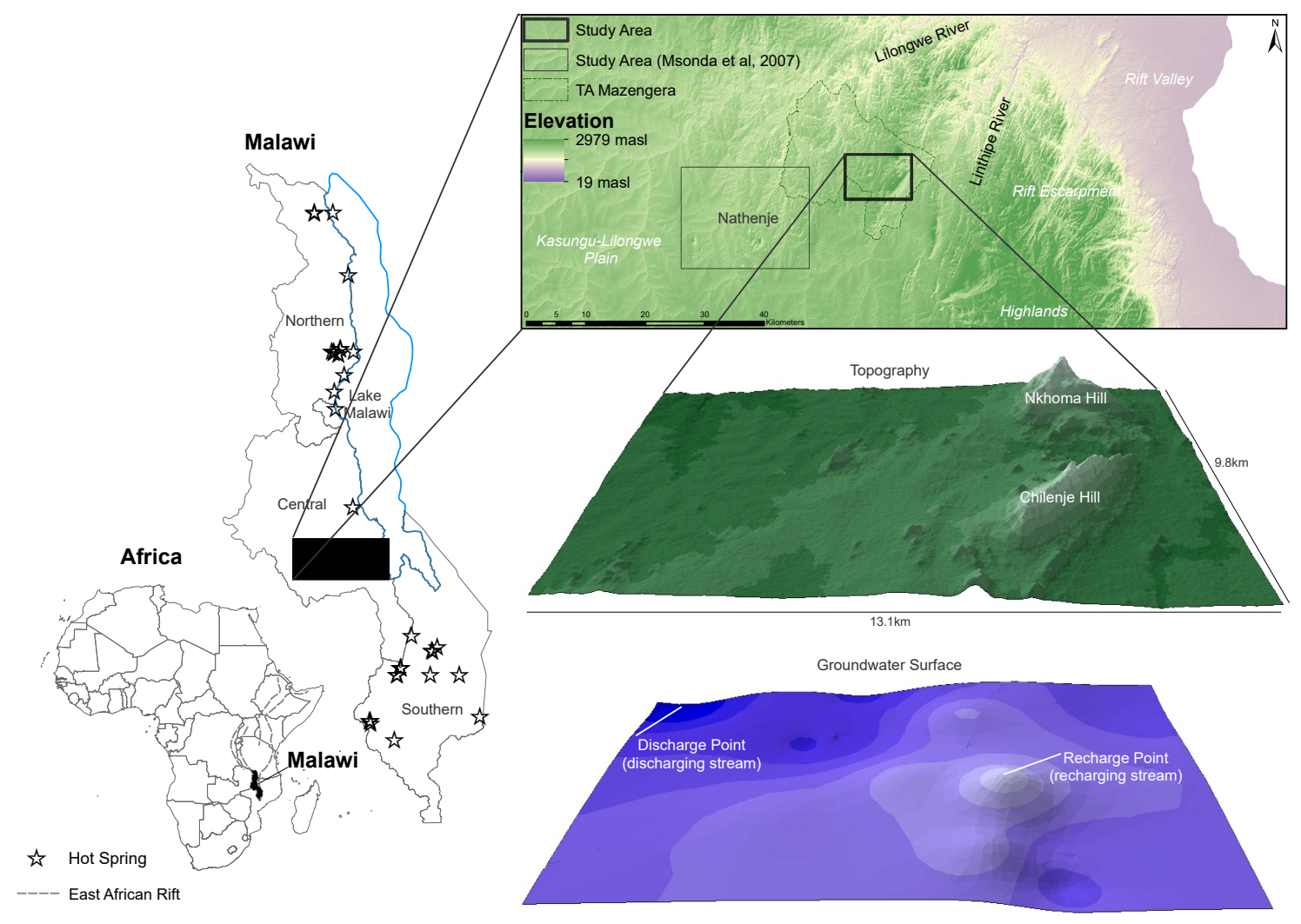

Figure 1. Location of study area within traditional authority (TA) Mazengera alongside Msonda et al. [13] study area at Nathenje area. The figure depicts Malawi's location within the east African rift system, marks the locations of all known hot springs and provides 3-D visualisation of the study area topography and drainage ( $2 \times$ vertical exaggeration), above a 3 -D visualisation of groundwater surface indicating the main recharge and discharge points ( $5 \times$ vertical exaggeration). 
Climate in the region is sub-tropical/semi-arid with distinct wet (November-April) and dry (May-October) seasons [25]. Monthly rainfall at the peak of the wet season (January) can reach an average of $222 \mathrm{~mm}$, but falls to $<1 \mathrm{~mm}$ at the dry season height (August). Mean annual precipitation averages $883 \mathrm{~mm}$ [26]. This type of climate is conducive to shallow groundwater fluoride enrichment that is found in a similar environment in northeast Sri Lanka. There, the semi-arid climate appears the main factor controlling enrichment due to a number of processes including low precipitation (recharge) and evaporative concentration [15]. Under semi-arid conditions, evapotranspiration at the surface where the water table is shallow may increase fluoride concentrations by a factor of 10-100 [3].

Fluoride occurrence in the study area had not been well characterised prior to this study. The Malawi Government internally released a 'Hydrogeology Atlas (2018)' containing six data points displayed simply as $<6 \mathrm{mg} / \mathrm{L}$ fluoride [27]. Only one study has conducted fluoride research nearby [13] (Figure 1) which documented fluoride occurrence in the groundwater of Nathenje area, about $20 \mathrm{~km}$ southwest of our study area (Figure 1). They sampled 176 boreholes over two years (2001-2002) during both wet and dry seasons. Basement geology comprised an identical range of gneiss lithologies to our study area, however, their western section has considerable colluvium (superficial sediment) which is mostly absent in our case. Over $50 \%$ of their samples had fluoride concentrations exceeding the WHO $1.5 \mathrm{mg} / \mathrm{L}$ drinking water standard. Concentrations were slightly higher during the dry season, but with spatial trends of highs and lows in concentration comparable across the seasons. Concentrations increased east-northeast leading them to hypothesise high fluoride may be anticipated out with their study area in a geological trend in that direction, towards TA Mazengera, but do not elaborate on specific lithologies. They concluded that in-situ weathering of fluoride-bearing minerals in the basement rock (biotite and hornblende in weathered gneiss) is the probable contributing source of fluoride to groundwater.

Highest groundwater fluoride is typically associated with the rift valley hydrothermal processes and alkaline igneous intrusions $[7,28]$. Low $\mathrm{Ca}^{2+}$ groundwaters were identified as target waters for elevated fluoride ( $\mathrm{Na}-\mathrm{HCO}_{3}, \mathrm{Na}-\mathrm{Cl}$-types) and the breakdown of biotite and hornblende (constituent phases of the basement gneisses of Malawi) is a probable source of fluoride, as fluoride can replace $\mathrm{OH}^{-}$groups in the crystal lattices of those minerals $[13,28]$. Water-bearing minerals such as biotite and muscovite are particularly susceptible to hydroxide-replacement [10].

\subsection{Geology and Hydrogeology}

The study area is $13.1 \mathrm{~km}$ by $9.8 \mathrm{~km}$ and is located on a plateau some distance from the main rift valley (Figure 1) and is characterised by a distinct lack of major fault systems (Figure 2). The nearest large fracture is $10 \mathrm{~km}$ northeast and the nearest rift fault $30 \mathrm{~km}$ in the same direction. It is inferred that rift valley processes may exert minimal influence. Structural separation from the rift valley results in no hot spring activity within $70 \mathrm{~km}$ of the study area (Figure 1). The nearest is to the northeast at Chikwidzi on the rift escarpment near a large rift-margin normal-fault. The hot spring also represents the closest recorded $>6 \mathrm{mg} / \mathrm{L}$ (Malawi standard) fluoride concentration [29].

The area comprises almost entirely weathered basement aquifer units [30]. Lithology is dominated by a mix of basement (meta-igneous and meta-sedimentary) rocks: augen gneiss (meta-granite), perthitic syenites, charnockitic gneiss and granulite, hornblende-biotite gneiss and calc-silicate marble. Gneissic foliations and lineations all strike southwest-northeast and dip $40-44^{\circ}$ northwest. Hornblende-biotite gneiss occurs as a plunging syncline within charnockitic gneiss and granulite in the northwest of the study area (Figure 2). Nkhoma and Chilenje hills in the east are perthitic syenites which have been intruded into the host basement causing isolated uplift of marbles and steep topography. Small, isolated dambo wetland of river and lacustrine alluvium occur in the south. The western edge contains colluvium deposits which form part of the eastern edge of the superficial deposits' aquifer of the Kasungu-Lilongwe Plain (Figure 2) [31]. 


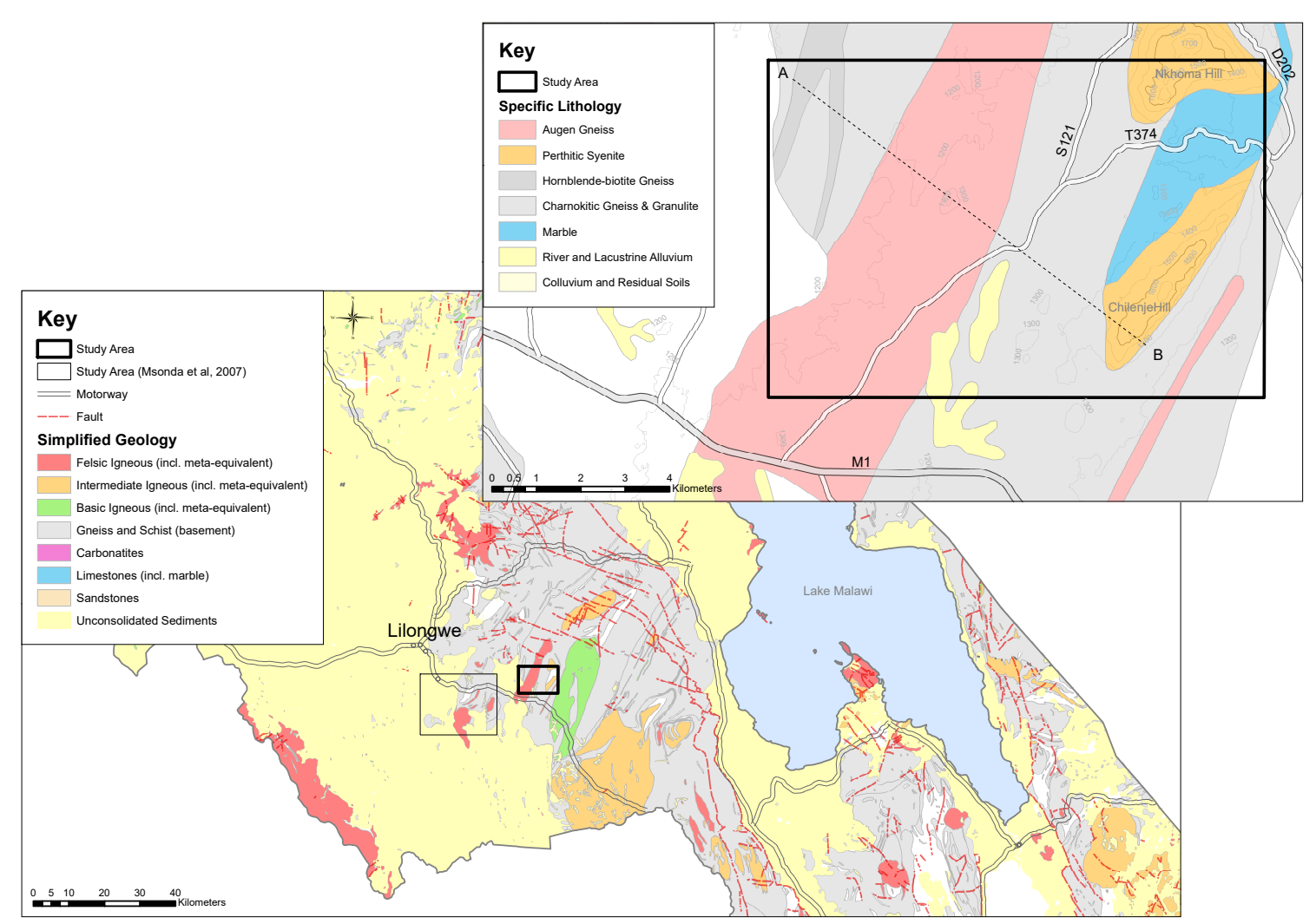

Figure 2. Regional geological map (simplified into lithological type-based on dominant composition) of central Malawi showing relative location of the study area to regional geological features. Map shows structural separation of the study area from the main rift valley (absence of faulting). Inset map shows the specific study area geology and the line of cross-section (A-B) from Figure 3.

Hydrogeological conceptualisation of the wider catchment flow regime from the uplands to Lake Malawi has been described [25]. Catchments originate in the plateau area east of the rift valley and drain northeast towards Lake Malawi, cross cutting the rift escarpment (Figure 1). The study area lies on a small ridge between the catchments for the Lilongwe and Linthipe Rivers and on the divide between catchments, with northwest and southeast flow from the Nkhoma and Chilenje Hills high points. Groundwater levels based on 16 water points (8 boreholes, 4 natural springs and 4 hand dug shallow wells) were used to conceptualise the water table. For the purposes of this conceptual model, only the aquifer west of Chilenje Hill was considered as the hill represents a flow barrier. The primary recharge point is a stream flowing onto an alluvial fan at the base of the northwest slope of Chilenje Hill, natural discharge occurs at a stream in the extreme northwest (Figure 1). Temporal changes in water table elevation (limited by boreholes going dry) suggest seasonal swings may be large at up to $8 \mathrm{~m}$ and probably reflect low storage. Geophysical data [32] show that regolith aquifers in this area have uneven thickness, ranging from 0-60 $\mathrm{m}$ in depth and are often semi-isolated due to uneven bedrock surface caused by folding. Bedrock often breaches the surface as linear gneiss mounds which strike southwest-northeast, perpendicular to local groundwater flow (assumed from consistent decrease in groundwater elevation southeast-northwest from Chilenje Hill). Pumping tests conducted at five sites within the study area (separate from geochemical sampling sites) show that hydraulic conductivity is variable but low in these aquifers ( $\mathrm{K}=0.03-0.2 \mathrm{~m} /$ day) [33]. A cross-sectional aquifer profile was developed, based on available geophysical and local groundwater data, and is presented in Figure $3 \mathrm{a}$.

The 'weathered basement' conceptual aquifer profile developed (Figure 3b) illustrates the key hydrogeological controls. A regolith aquifer containing saprock and saprolite layers of varying thickness is the main storage unit. Localised fracturing in underlying basement rock increases permeability and 
limited storage where present, however, the lateral extent of permeability remains unknown. Uneven bedrock surfaces create isolated sub-aquifer units which may become increasingly isolated during the dry season when groundwater levels are low. The aquifer exists under semi-confined conditions due to discontinuous clay layers at the base of the laterite layer. Boreholes drilled where there is clay often have resting water levels above the original water strike [34]. Recharge occurs at the base of the Nkhoma and Chilenje Hills (Figure 1), at alluvial fans, places where unaltered and fractured gneiss is exposed as gneiss mounds and at areas where topsoil/laterite is absent exposing saprolite [32] (Figure 3). Higher groundwater levels may facilitate increased sub-aquifer connectivity (flushing) during the wet season, down-hydraulic-gradient from the Nkhoma and Chilenje Hills in northwest and southeast directions, following decreasing altitude (Figure 3), however this is assumed to be minimal based on low hydraulic conductivities [33] and perpendicular flow barriers.

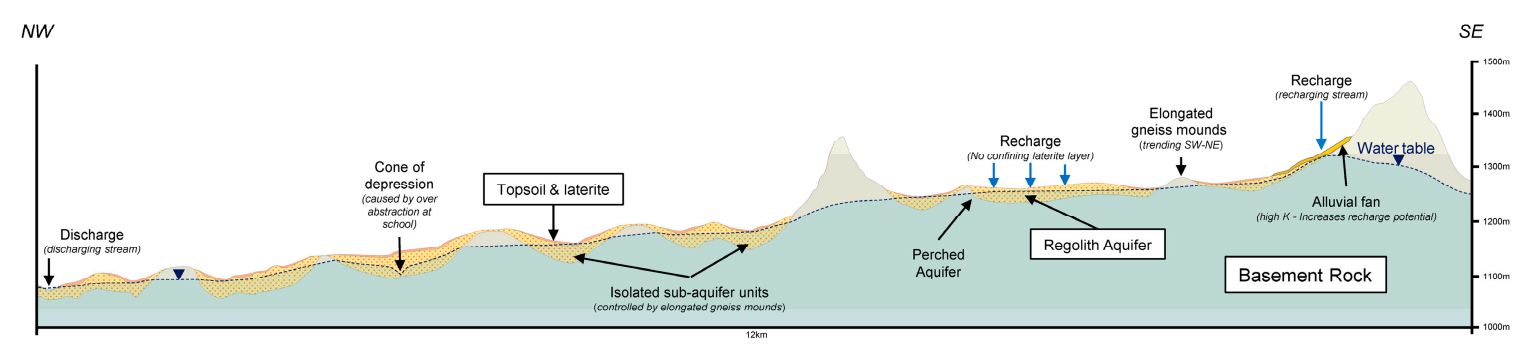

(a)

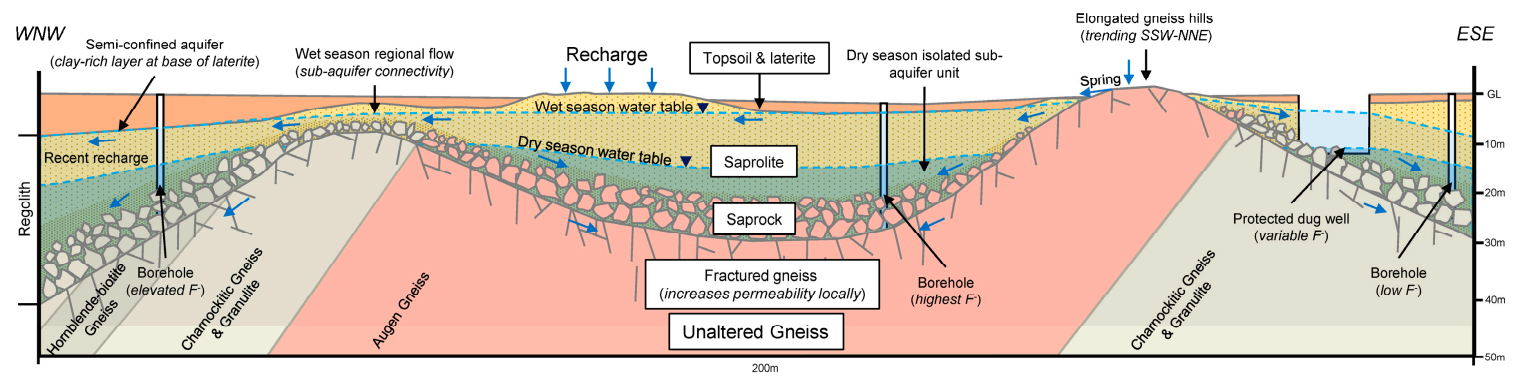

(b)

Figure 3. (a) - Aquifer cross-section (A-B) of study area showing decreasing altitude and groundwater levels southeast-northwest from recharge at high elevation to discharge at low elevation (vertically exaggerated), topography surface, aquifer depth and water table levels calculated from data. The figure shows semi-isolated nature of regolith aquifer units. (b)-Schematic hydrogeological conceptual model (not to scale).

Groundwater resource development is mainly boreholes accounting for $66 \%$ of water points (incl. surface water). Drilling may be with little geological or hydrogeological knowledge. Boreholes are drilled to an average depth of $47 \mathrm{~m}$ (range: $34-66 \mathrm{~m}$ ) and cover all lithologies. A smaller proportion of hand dug shallow wells (3-10 m depth) exists (19\% of water points), $81 \%$ of which are protected at the surface by hand-pumps. The unprotected wells have open sections and are often covered simply by a piece of wood. There are also some natural springs ( $2 \%$ of all water points) at the base of the hills. There is a partially functional piped water supply network in the area (12\%) where water is transported from gravity-fed systems and a reticulated borehole, via pipes to various kiosks. Piped supplies were not sampled in this study.

\section{Materials and Methods}

\subsection{Groundwater Survey}

Groundwater samples (39) were collected to investigate the geochemical relationship between groundwater and local geology and to test our hypothesised geological control. These covered the 
three main lithological aquifer sources: augen gneiss, hornblende-biotite gneiss and charnockitic gneiss and granulite. They also covered the range of groundwater supply types: 34 boreholes, three hand dug shallow wells and two natural springs. They comprised $16 \%$ of all water points in the area and were evenly distributed. All sampled boreholes and shallow wells were located in regolith and both springs located in bedrock. Samples were collected in November 2019 (wet season) in 1 litre plastic bottles and stored away from light at $4{ }^{\circ} \mathrm{C}$. Purging of boreholes fitted with Afridev hand-pumps was not necessary as all were regularly used prior to sampling, natural springs and shallow wells were sampled in situ. Samples were shipped to Scotland for analysis at the University of Strathclyde. Water temperature was measured at site, using portable measuring equipment. Electrical conductivity (EC), total dissolved solids (TDS) and $\mathrm{pH}$ were measured upon delivery at the laboratory using a Mettler Toledo meter (Model MPC 227). All samples were then filtered and anions $\left(\mathrm{F}^{-}, \mathrm{Cl}^{-}, \mathrm{NO}_{2}{ }^{-}, \mathrm{Br}^{-}, \mathrm{NO}_{3}{ }^{-}, \mathrm{PO}_{4}{ }^{3-}, \mathrm{SO}_{4}{ }^{2-}\right)$ were analysed by ion chromatography (IC Metrohm, 850 Professional) and cations $\left(\mathrm{Ca}^{2+}, \mathrm{Mg}^{2+}, \mathrm{Na}^{+}\right.$, $\mathrm{K}^{+}$) analysed by a inductively coupled plasma optical emission spectrometer (ICP OES) (iCAP 6200, Thermo Scientific, Waltham, MA, USA). Total alkalinity $\left(\mathrm{CaCO}_{3}\right)$ was analysed by KONE Aquakem v. 7.2.AQ2 with results multiplied by a factor of 1.22 to estimate total alkalinity $\left(\mathrm{HCO}_{3}{ }^{-}\right)$. In total, 35 of the samples ion-balanced within the conventionally accepted $\pm 5 \%$ analysis uncertainty, the remaining four samples within $\pm 10 \%$. The latter were excluded from geochemical analyses but not excluded from fluoride spatial analyses, or analyses where fluoride is the only geochemical component (as fluoride contribution to total anions was $<2 \%$ in all four samples, therefore, it is unlikely that fluoride would influence the overall ion balance).

\subsection{Survey Data}

A total of 6804 households in the TA Mazengera study area were visited by Government of Malawi enumerators as part of a wider SDG 6 survey. Dental fluorosis proxy indicator data from this survey was provided to link fluoride occurrence in the area to human health risks. The area reflects a typical low-income, rural population for central Malawi where most of the population gather their daily water from public water points. Only $9.6 \%$ of households surveyed had access to a public piped water supply. The survey data was comprised of anonymised questionnaire responses gathered from doorstep interviews with residents on their water use. One question concerned visible symptoms of dental fluorosis.

Survey results provide qualitative proxy information on the visible symptoms of dental fluorosis, but do not constitute a medical or human health survey and results are not definitive in case diagnosis. Results are hence indicative of the condition based on recording of visual symptoms (brown/black staining of the teeth). No inclusion or exclusion criteria were applied. It is recognised that there could be a misappropriation of potential fluorosis respondents who might have had other medically confirmed dental problems, or a history of tobacco (very low in Malawi) or kola use that could yield similar symptoms [35]. Such caveats are recognised.

\subsection{Risk Evaluation}

\subsubsection{Mapping Risk}

Demonstration of geological control on groundwater fluoride occurrence is significant as it would permit use of available geological maps to effectively map fluoride risk; i.e., certain lithologies would map as high risk, others intermediate and other low risk. Proving this hypothesis for the study area (ultimately shown herein) allowed a geological fluoride risk map to be developed for the study area based on statistical analysis of groundwater fluoride data with corresponding host lithology. An arbitrary grading system was developed to represent risk of groundwater with fluoride concentrations in excess of the WHO standard $(1.5 \mathrm{mg} / \mathrm{L})$ from each lithology in the study area: Grade 0 (unknown risk-no corresponding groundwater fluoride data); Grade 1 ( $<20 \%$ risk); and Grade $2(>60 \%$ risk). Each lithology was represented on the map as a zone with its corresponding risk 
grade. The map was based solely on the influence of lithological composition to groundwater fluoride concentrations as it assumes very reasonably in the Malawian rural setting that anthropogenic fluoride inputs were insignificant. The map also assumes the local rock mapped has the dominant influence on its groundwater, rather than a neighboring geological unit from which it may have received some inflows. In addition, the evolution of groundwater hydrochemistry along a flow path within the mapped locality does not result in fluoride concentration changes sufficient to alter the host rock risk grading.

\subsubsection{Human Health Risk Assessment}

To support policy change on fluoride standards in rural drinking water in Malawi, a 'human health risk assessment' was undertaken on each of the water points sampled for geochemistry. The method was based upon the approach introduced by the United States Environmental Protection Agency (USEPA) as a tool to "assess the nature and possibility of adverse health effects in humans who consume highly contaminated water" [36,37]. Similar studies have been conducted since in India and Iran $[36,38,39]$. The method involves the calculation of a non-carcinogenic risk index, also known as a 'hazard quotient' (HQ) (dimensionless) detailed below [40,41] (in [38]): chronic daily intake (CDI) is calculated (1) [40,41] (in [38]) and defined by the following parameters:

$$
C D I=\frac{C * D I * F * E D}{B W * A T}
$$

C-Fluoride content in drinking water $(\mathrm{mg} / \mathrm{L})$

DI-Daily Water Intake (1/day)

F-Exposure Frequency (days/year)

ED—Exposure Duration (years)

BW-Average Body Weight $(\mathrm{kg})$

AT-Averaging Time for non-carcinogens (days)

The HQ is then defined as follows (2) [40,41] (in [38]):

$$
H Q=\frac{C D I}{R f D}
$$

CDI—Chronic Daily Intake (mg/kg/day)

RfD—Oral Reference Dose (mg/kg/day)

The HQ value indicates the "ratio of the potential exposure to a substance and the level at which no adverse effects are expected as a result of exposure. If $\mathrm{HQ}>1$, adverse effects are possible" [39]. $\mathrm{HQ}$ represents an indication of potential risk from fluoride at any water point. Three risk categories were applied: children (aged 6 years old), children (aged 12 years old) and adults ( $>19$ years old) (adapted from Qasemi et al. [38]). The values used for Equations (1) and (2) were from previous studies [38,39] (Table 1). BW (body weight) and DI (daily water intake) values were based on averages for the age groups chosen and broadly represent the study area population. Once calculated, HQ values were further analysed to explore statistical relationships with geology. This was achieved by comparing calculated proportions of $\mathrm{HQ}$ values $>1$ for each lithology. 
Table 1. Values used to calculate the hazard quotient (HQ) for the study area water points per age group (adapted from: [38,39]). ' $\mathrm{C}$ ' values are not included as they represent individual fluoride concentrations for each water point and vary from water point to water point.

\begin{tabular}{ccccc}
\hline $\begin{array}{c}\text { Risk Exposure } \\
\text { Factors }\end{array}$ & Values for Age Groups & & Unit \\
\hline & Adults (>19 Years Old) & Children (12 Years Old) & Children (6 Years Old) & $(\mathrm{mg} / \mathrm{L})$ \\
C & & & & $(1 / \mathrm{day})$ \\
DI & 2 & 1.7 & 1 & $($ days/year) \\
F & 365 & 365 & 365 & $($ years $)$ \\
ED & 19 & 12 & 6 & $(\mathrm{~kg})$ \\
BW & 70 & 40 & 2190 & $($ days $)$ \\
AT & 6935 & 4380 & 0.06 & $(\mathrm{mg} / \mathrm{kg} / \mathrm{day})$ \\
RfD & 0.06 & 0.06 & & \\
\hline
\end{tabular}

\section{Results}

\subsection{Hydrochemical Observations}

Groundwater in the study area is exclusively $\mathrm{Ca}-\mathrm{Mg}-\mathrm{HCO}_{3}$ type. Hydrochemical data $\left(\mathrm{HCO}_{3}{ }^{-}\right.$, $\mathrm{Ca}^{2+}, \mathrm{Na}^{+}, \mathrm{Mg}^{2+}, \mathrm{F}^{-}$and $\mathrm{pH}$ ) were plotted with TDS alongside a TDS map (Figure 4). Groundwater is least mineralised around the Nkhoma and Chilenje Hills. Two natural springs were sampled at the base of the southeast slope of Chilenje Hill. These springs contained the least mineralised groundwater. Increasing fluoride concentrations follow a southeast-northwest trend, with the highest fluoride at locations with the highest $\mathrm{HCO}_{3}{ }^{-}, \mathrm{Na}^{+}$and $\mathrm{Mg}^{2+}$. Low TDS samples from Augen gneiss display notably higher (an order of magnitude) $\mathrm{Na}^{+}, \mathrm{Mg}^{2+}$ and $\mathrm{F}^{-}$signatures than low TDS samples from charnockitic gneiss and granulite. Concentrations then increase with TDS following a similar trend in both lithologies. Geochemical data can be viewed in Table S2 in the supplementary materials.
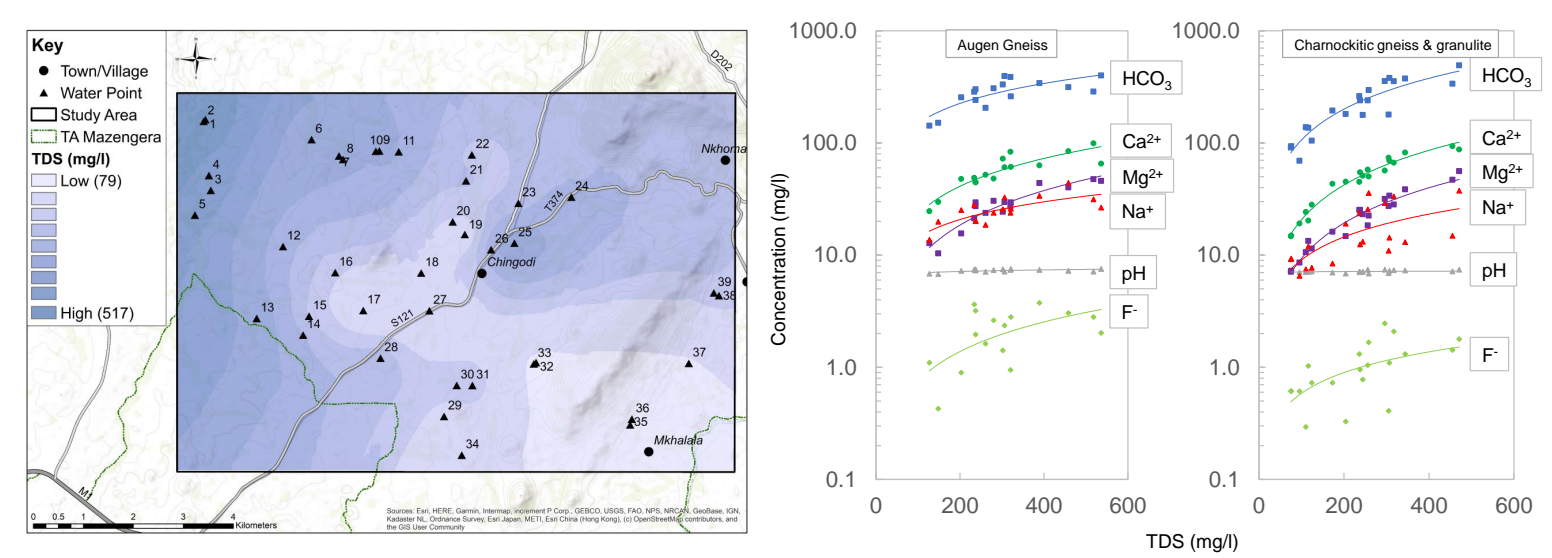

Figure 4. Total dissolved solids (TDS) map of the study area with log plots of relevant hydrochemical concentrations vs. TDS. Map shows TDS values increasing northwest in the direction of decreasing altitude. Graphs show increasing trends in relevant ions with increasing TDS (as seen on the map).

Correlation is not observed between fluoride concentrations and temperature data that span $21-27^{\circ} \mathrm{C}$ (groundwater temperatures in Malawi not influenced by geothermal sources are typically around $20-30{ }^{\circ} \mathrm{C}$ [7]). Temperatures appear to increase northwest with elevation decline (Figure 1) corresponding to where the water table may be shallow and more vulnerable to surface temperature fluctuations.

Fluoride was plotted with $\mathrm{Ca}^{2+}$ alongside fluorite $\left(\mathrm{CaF}_{2}\right)$ equilibrium (Figure 5). For water with TDS above $200 \mathrm{mg} / \mathrm{L}$, a few water samples approach fluorite saturation but this may be a common ion effect with calcite. Low TDS samples (least mineralised-recent recharge) all plot well below equilibrium 
displaying both low $\mathrm{Ca}^{2+}$ and low fluoride (Figure 5); all are located near the foot of the Nkhoma and Chilenje Hills (Figure 1).

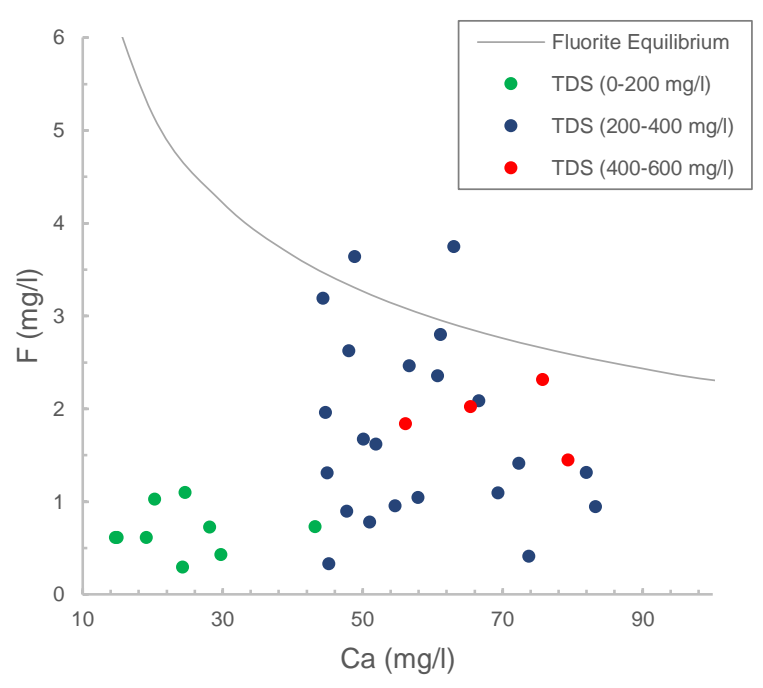

Figure 5. Plot of calcium versus fluoride showing equilibrium for the mineral fluorite $\left(\mathrm{CaF}_{2}\right)$. The fluorite equilibrium curve was calculated from $\{\mathrm{F}\}=\left(K_{\text {eq }} /\{\mathrm{C} a\}\right)^{0.5}$ that assumes equality of the ion activity product (IAP) with the equilibrium constant $\left(K_{e q}\right)\left(3.7 \times 10^{-11}\right)$.

A Gibbs diagram plot confirms rock weathering is the dominant process controlling groundwater composition (Figure 6). Just a slight incline towards evaporation suggests minimal evaporation influence on shallow groundwater geochemistry in this system.

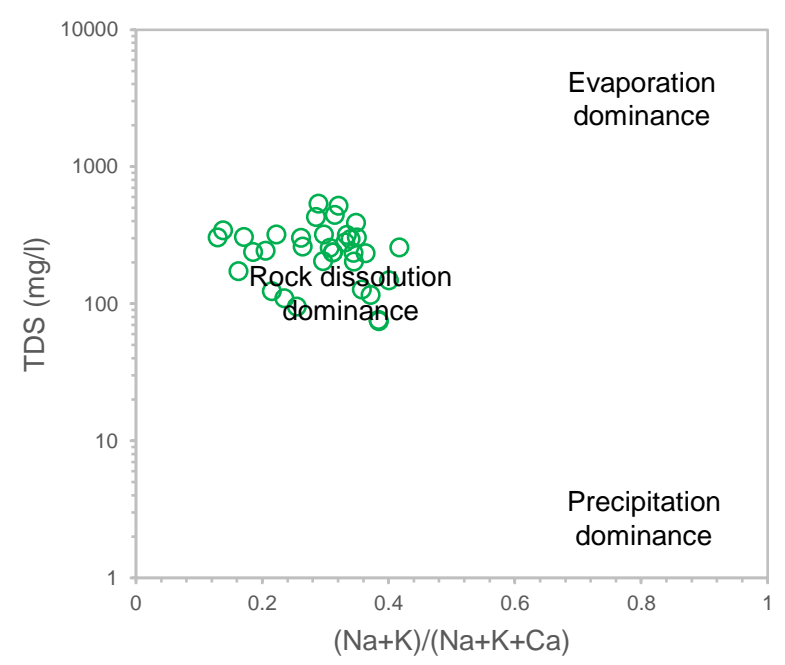

Figure 6. Gibbs diagram of study area groundwater samples showing dominance of rock dissolution. Calculations are shown on axes.

\subsection{Geological Controls on Fluoride Occurrence}

Fluoride concentrations were lowest in the southeast where the dominant lithology is charnockitic gneiss and granulite, becoming progressively more elevated northwest where the highest fluoride concentrations were located within alkaline meta-igneous rocks (augen gneiss). This lithology contains all fluoride concentrations $>3 \mathrm{mg} / \mathrm{L}$. Concentrations then decrease slightly further northwest where the dominant lithology returns to Charnockitic gneiss and granulite, with interbedded hornblende-biotite 
gneiss (Figure 7). No data were available for perthitic syenite, calc-silicate marble or superficial deposits so their (fluoride) hydrochemical profile remains unknown.

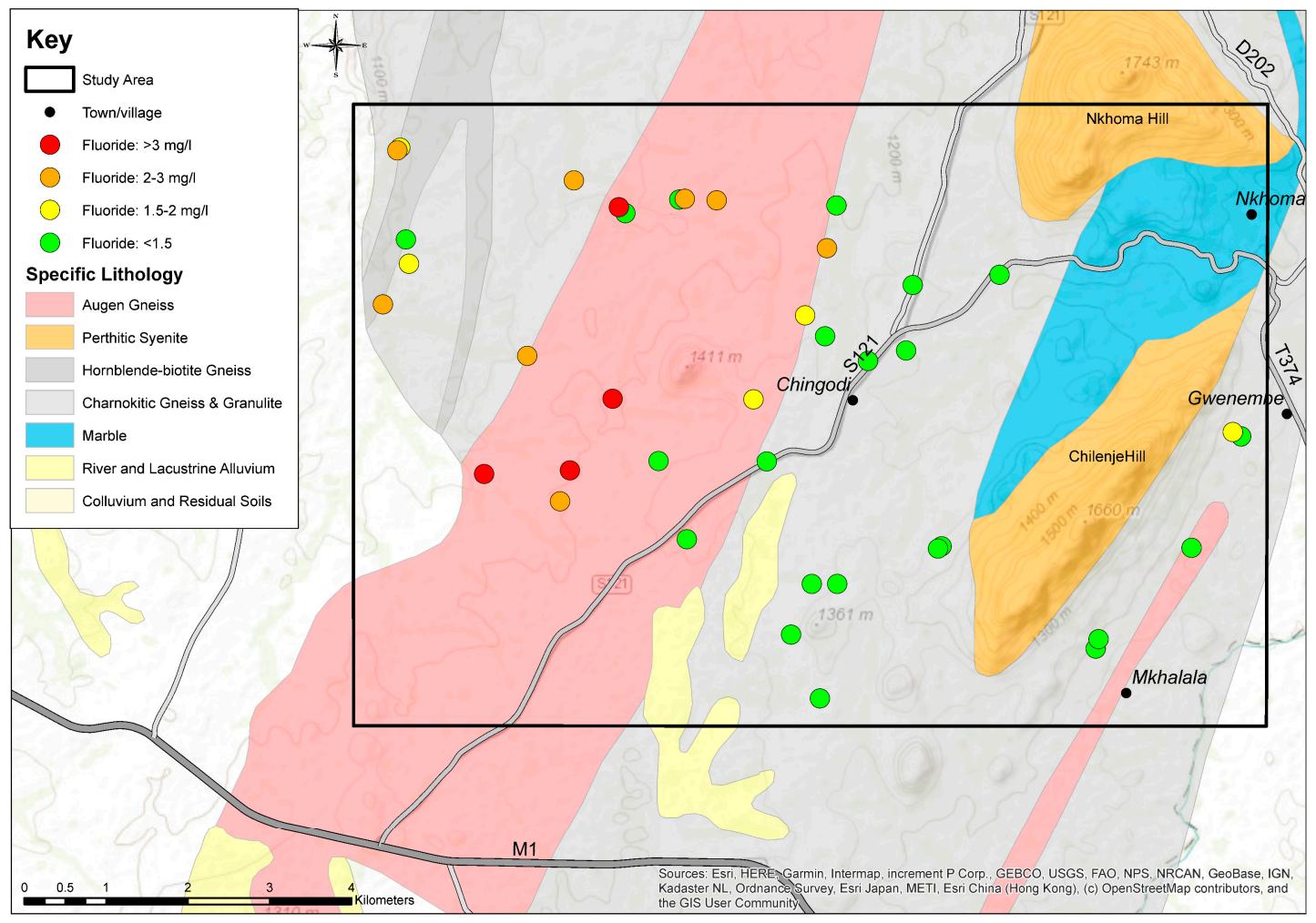

Figure 7. Map showing fluoride data in the study area plotted onto local geology.

A box and whisker plot to investigate the specific lithology-fluoride relationships (Figure 8) shows Charnockitic gneiss and granulite producing the lowest groundwater fluoride with only $20 \%$ of samples exceeding the WHO standard for fluoride in drinking water of $1.5 \mathrm{mg} / \mathrm{L}$. A total of $10 \%$ of groundwater samples in this lithology exceeded $2 \mathrm{mg} / \mathrm{L}$ and none exceeded $3 \mathrm{mg} / \mathrm{L}$. Augen gneiss (alkaline composition) on the other hand had $69 \%$ of samples exceeding the WHO standard. This lithology also possesses the highest fluoride concentrations with $56 \%$ of samples exceeding $2 \mathrm{mg} / \mathrm{L}$ and $25 \%$ exceeding $3 \mathrm{mg} / \mathrm{L}$ (Table S1-Supplementary Materials). Hornblende-biotite gneiss sits between those lithologies with respect to fluoride concentrations. Low sample numbers for this lithology prevent definitive conclusions, although the expectation would not differ much from those measured values as it contains more fluoride-bearing minerals (relatively) than charnockitic gneiss (biotite and hornblende) and less sodium than the augen gneiss (contains an abundance of Na-plagioclase megacrysts) (Figure 4) which makes it a fluoride source candidate. It has been provisionally included in the (later) risk map for this reason, recognising the need for greater sample numbers. 


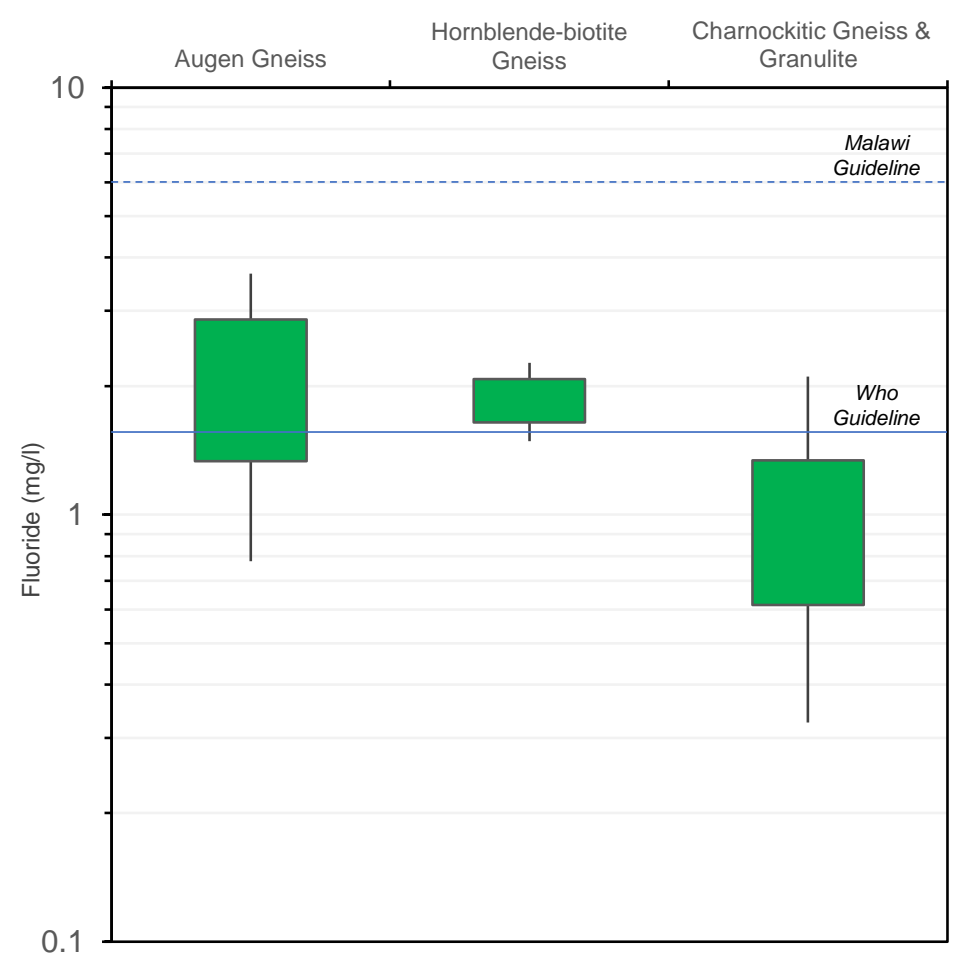

Figure 8. Box and whisker plot of fluoride concentrations (5th, 25th, 75th and 95th percentiles) in the various lithological units (augen gneiss $(n=16)$, hornblende-biotite Gneiss $(n=3)$ and charnockitic gneiss and granulite $(n=20))$.

\subsection{Dental Fluorosis Indicators}

Survey responses provide a preliminary indication of dental fluorosis prevalence and are categorised in Table 2 with corresponding host lithologies (only responses within lithologies with groundwater fluoride data are included). Statistically, charnockitic gneiss and granulite had the lowest percentage of "yes" responses at $22 \%(6 \%$ below the average; $n=1022)$. Augen gneiss hosts the highest percentage of "yes" responses at $41 \%(13 \%$ above the average; $n=853)$ (Table 2$)$. These results concur with our hydrochemical and geological data, illustrating that groundwater within augen gneiss is the most vulnerable to fluoride, followed by hornblende-biotite gneiss (again, recognising relative low sample numbers for this lithology; $n-134)$ and finally charnockitic gneiss and granulite. This is an important result substantiating our hypothesis.

Table 2. Summary statistics of dental fluorosis indicator data and corresponding geology.

\begin{tabular}{ccccc}
\hline Question Asked & \multicolumn{3}{c}{ Lithology } & Total \\
\hline $\begin{array}{c}\text { "Does anyone in your household suffer } \\
\text { from brown-black staining of } \\
\text { the teeth?" }\end{array}$ & $\begin{array}{c}\text { Augen } \\
\text { gneiss }\end{array}$ & $\begin{array}{c}\text { Hornblende-biotite } \\
\text { gneiss }\end{array}$ & $\begin{array}{c}\text { Charnockitic } \\
\text { gneiss and } \\
\text { granulite }\end{array}$ \\
\hline $\begin{array}{c}\text { Total responses } \\
\text { "Yes" responses } \\
\text { \% yes }\end{array}$ & 2070 & 134 & 4600 & 6804 \\
& 853 & 54 & 1022 & 1929 \\
\hline
\end{tabular}

\subsection{Risk Evaluation}

\subsubsection{Risk Map}

Statistical analysis of fluoride-lithology data may be hence used to map geological fluoride risk zones (Figure 9). Both augen gneiss and hornblende-biotite gneiss lithologies host $>60 \%$ risk $(68.8 \%$ 
and $66.7 \%$ respectively) of producing drinking water in excess of the WHO standard $(1.5 \mathrm{mg} / \mathrm{L})$ and are thus mapped as Grade 2 (highest risk). Statistically, charnockitic gneiss and granulite displayed the least risk $(<20 \%)$ and were mapped as Grade 1 . The blank areas were mapped as Grade 0 as no hydrochemical data were available with which to perform statistical analyses. Red zones (Grade 2 ), therefore, represent areas where there is $>60 \%$ risk of abstracted groundwater used for supply producing enough fluoride to cause dental fluorosis (assuming regular consumption from the same water point). Such geology-based risk maps, calibrated to fluoride occurrence, may provide the foundation for the development of risk maps in other areas of similar mapped geologies for which groundwater fluoride data may not exist. With increased groundwater fluoride occurrence data coverage of the presently Grade 0 (unknown) areas it is anticipated greater resolution of the grading system may be possible with increased numbers of grades to characterise the system.

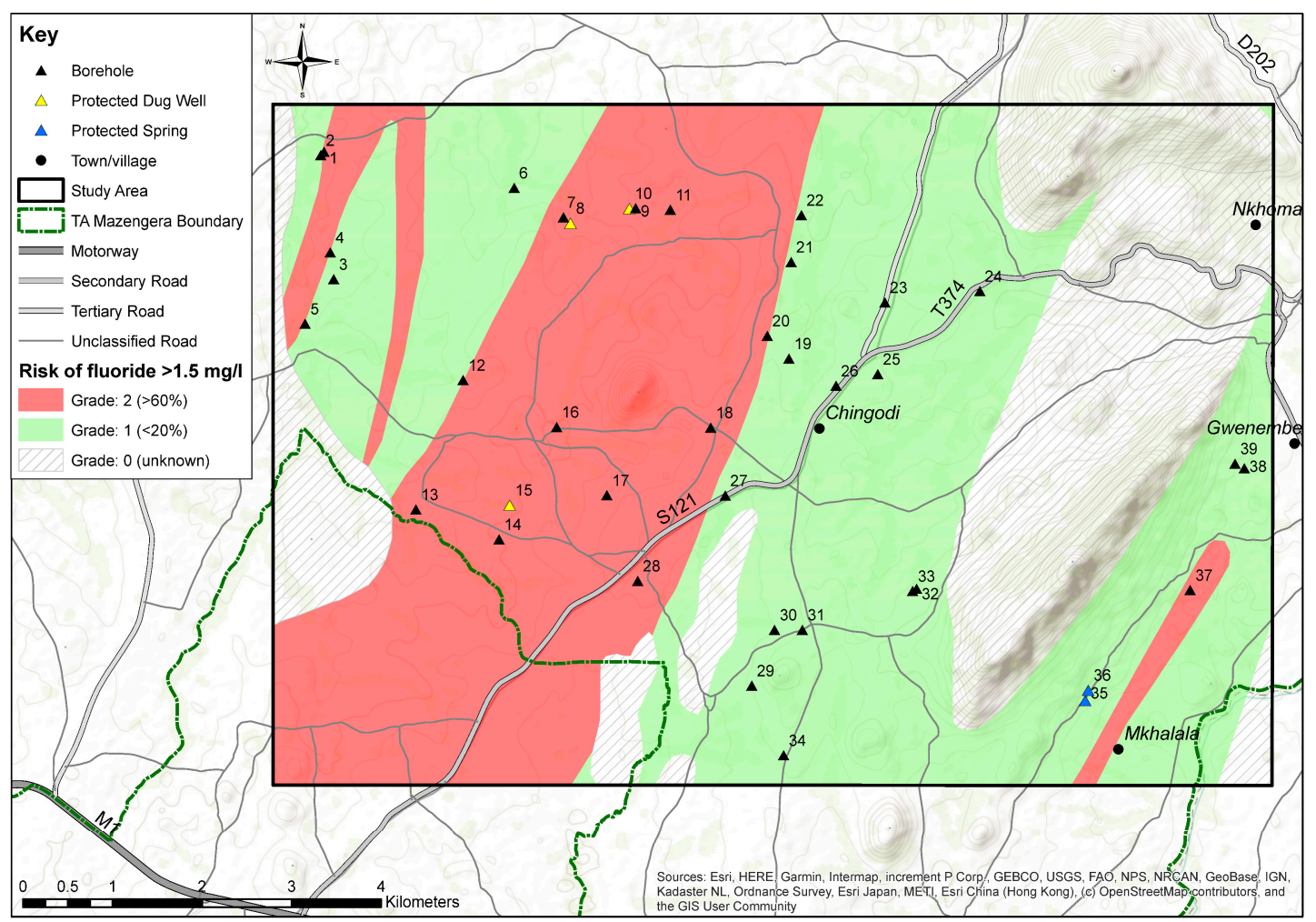

Figure 9. Geological fluoride risk map showing lithologies with risk of groundwater fluoride concentrations $>1.5 \mathrm{mg} / \mathrm{L}$ as graded zones. Blank zones (Grade 0) reflect areas where geological data are available but corresponding hydrochemical data are not. Sampled water points are shown with their corresponding sample numbers.

\subsubsection{Human Health Risk Assessment}

$74 \%(n=29)$ of sampled water points had HQ values $>1$ for children under the age of 6 , indicating possible and increasing risk of dental fluorosis from exposure to fluoride in drinking water from those groundwater points (Table 3). $44 \%(n=17)$ of water points had HQ values $>1$ for children under the age of 12 and $28 \%(n=11)$ had HQ values $>1$ for adults over 19 years old. The latter also included all children under 12 years old. $26 \%(n=10)$ had HQ values $<1$ for all age groups and appear safe for anyone to drink from. Water Point 13, which displayed the highest HQ value (4.11), also displayed the highest fluoride concentration in the study area $(3.75 \mathrm{mg} / \mathrm{L})($ Table 3$)$. 
Table 3. Calculated HQ values for each age group and each water point from the study area. HQ values $>1$ shown in bold.

\begin{tabular}{|c|c|c|c|c|c|}
\hline \multirow[t]{2}{*}{$\begin{array}{l}\text { Sample } \\
\text { Number }\end{array}$} & \multirow[t]{2}{*}{ Water Point Type } & \multirow[t]{2}{*}{$\begin{array}{l}\text { Fluoride } \\
(\mathrm{mg} / \mathrm{L})\end{array}$} & \multicolumn{3}{|c|}{ Hazard Quotient (HQ) } \\
\hline & & & $\begin{array}{c}\text { Adults } \\
(>19 \text { years old })\end{array}$ & $\begin{array}{c}\text { Children } \\
\text { (12 years old) }\end{array}$ & $\begin{array}{c}\text { Children } \\
\text { (6 years old) }\end{array}$ \\
\hline 1 & Borehole & 1.84 & 0.86 & 1.28 & 2.00 \\
\hline 2 & Borehole & 2.02 & 0.95 & 1.42 & 2.22 \\
\hline 3 & Borehole & 1.78 & 0.86 & 1.28 & 2.00 \\
\hline 4 & Borehole & 1.45 & 0.67 & 0.99 & 1.56 \\
\hline 5 & Borehole & 2.31 & 1.10 & 1.63 & 2.56 \\
\hline 6 & Borehole & 2.08 & 1.00 & 1.49 & 2.33 \\
\hline 7 & Borehole & 3.04 & 1.43 & 2.13 & 3.33 \\
\hline 8 & Protected dug well & 1.41 & 0.67 & 0.99 & 1.56 \\
\hline 9 & Borehole & 2.80 & 1.33 & 1.98 & 3.11 \\
\hline 10 & Protected dug well & 0.89 & 0.43 & 0.64 & 1.00 \\
\hline 11 & Borehole & 2.80 & 1.33 & 1.98 & 3.11 \\
\hline 12 & Borehole & 2.46 & 1.19 & 1.77 & 2.78 \\
\hline 13 & Borehole & 3.75 & 1.76 & 2.62 & 4.11 \\
\hline 14 & Borehole & 2.36 & 1.14 & 1.70 & 2.67 \\
\hline 15 & Protected dug well & 3.64 & 1.71 & 2.55 & 4.00 \\
\hline 16 & Borehole & 3.19 & 1.52 & 2.27 & 3.56 \\
\hline 17 & Borehole & 0.43 & 0.19 & 0.28 & 0.44 \\
\hline 18 & Borehole & 1.62 & 0.76 & 1.13 & 1.78 \\
\hline 19 & Borehole & 1.03 & 0.48 & 0.71 & 1.11 \\
\hline 20 & Borehole & 1.96 & 0.95 & 1.42 & 2.22 \\
\hline 21 & Borehole & 2.62 & 1.24 & 1.84 & 2.89 \\
\hline 22 & Borehole & 1.31 & 0.62 & 0.92 & 1.44 \\
\hline 23 & Borehole & 0.78 & 0.38 & 0.57 & 0.89 \\
\hline 24 & Borehole & 1.09 & 0.52 & 0.78 & 1.22 \\
\hline 25 & Borehole & 1.42 & 0.67 & 0.99 & 1.56 \\
\hline 26 & Borehole & 1.31 & 0.62 & 0.92 & 1.44 \\
\hline 27 & Borehole & 0.29 & 0.14 & 0.21 & 0.33 \\
\hline 28 & Borehole & 0.95 & 0.43 & 0.64 & 1.00 \\
\hline 29 & Borehole & 0.33 & 0.14 & 0.21 & 0.33 \\
\hline 30 & Borehole & 0.95 & 0.48 & 0.71 & 1.11 \\
\hline 31 & Borehole & 0.41 & 0.19 & 0.28 & 0.44 \\
\hline 32 & Borehole & 0.61 & 0.29 & 0.43 & 0.67 \\
\hline 33 & Borehole & 0.73 & 0.33 & 0.50 & 0.78 \\
\hline 34 & Borehole & 0.73 & 0.33 & 0.50 & 0.78 \\
\hline 35 & Protected spring & 0.61 & 0.29 & 0.43 & 0.67 \\
\hline 36 & Protected spring & 0.61 & 0.29 & 0.43 & 0.67 \\
\hline 37 & Borehole & 1.10 & 0.52 & 0.78 & 1.22 \\
\hline 38 & Borehole & 1.05 & 0.48 & 0.71 & 1.11 \\
\hline 39 & Borehole & 1.67 & 0.81 & 1.20 & 1.89 \\
\hline
\end{tabular}

Statistical analysis of HQ values with corresponding host lithology (Table 4) demonstrated that for all age groups, augen gneiss carries the most groundwater fluoride risk. For children under the age of 6: $94 \%$ of water points in this lithology displayed HQ values $>1$. Statistically, hornblende-biotite gneiss appeared to be highest risk lithology for that age group ( $100 \%$ of HQ values $>1)$ but again, low sample numbers $(n=3)$ prevents definitive conclusion. The lithology with least fluoride risk was charnockitic gneiss and granulite with only $55 \%$ of water points displaying HQ values $>1$. For children under the age of 12: water points within augen gneiss, again, were the most vulnerable with $69 \%$ displaying HQ values $>1.67 \%$ of water points within hornblende-biotite gneiss have HQ values $>1$ and only $20 \%$ for charnockitic gneiss and granulite. The same trend was observed in adults over the age of 19 (Table 4). 
These results again support augen gneiss as the dominant source of groundwater fluoride, therefore posing the highest dental fluorosis risk.

Table 4. Summary statistics for HQ values $>1$ per lithology. Values are percentages of sampled water points with an HQ value $>1$ for each lithology.

\begin{tabular}{ccccc}
\hline Lithology & $n$ & \multicolumn{2}{c}{ Hazard Quotient (HQ) = > 1 } \\
\hline & & $\begin{array}{c}\text { Adults } \\
\text { (>19 years old) }\end{array}$ & $\begin{array}{c}\text { Children } \\
\text { (12 years old) }\end{array}$ & $\begin{array}{c}\text { Children } \\
\text { (6 years old) }\end{array}$ \\
\hline Augen gneiss & 16 & $50.00 \%$ & $68.75 \%$ & $93.75 \%$ \\
Hornblende-biotite gneiss & 3 & $33.33 \%$ & $66.66 \%$ & $100.00 \%$ \\
Charnockitic gneiss and granulite & 20 & $10.00 \%$ & $20.00 \%$ & $55.00 \%$ \\
All & 39 & $28.21 \%$ & $43.59 \%$ & $74.36 \%$ \\
\hline
\end{tabular}

\section{Discussion}

\subsection{Geological Fluoride}

Augen gneiss poses the highest potential for elevated groundwater fluoride, ascribed to its granitic-type (alkaline) composition. The augen gneiss is a metamorphosed granite and hosts an abundance of fluoride-bearing minerals such as hornblende, biotite (and accessory apatite) along with characteristic Na-feldspar mega-crysts which are an additional source of sodium (recognised to be conducive to fluoride enrichment). Solubility of fluoride-bearing minerals is generally low. One dimensional reactive-transport equations have shown long residence times are required to produce appreciable concentrations of fluoride in groundwater from silicate rocks, however, higher reactive surface area can significantly increase the rate at which concentrations accumulate [42]; meaning, weathered basement aquifers will have significantly increased fluoride mobilisation potential. Samples represent recent recharge (low mineralisation) and it is likely that increased reactive surface area of the weathered basement aquifer (Saprock, saprolite and fractured gneiss) is a key control on the release of fluoride and may account for observed concentrations. Our geological, geochemical and hydrogeological data support this hypothesis.

Fluorite solubility is usually expected to control fluoride concentrations in groundwater leading to a proportional relationship between $\mathrm{F}^{-}$and $\mathrm{Ca}^{2+}$ ions in solution. Clay minerals and fine sands are moderate adsorbents for fluoride [3], while clay minerals can also be a source of $\mathrm{Na}^{+}$for ion exchange with $\mathrm{Ca}^{2+}$, furthering the potential for fluoride enrichment [3,7]. Water type, therefore, plays an important role in fluoride concentration. Lowest fluoride is expected in recharging water, naturally increasing with groundwater evolution through: $\mathrm{Ca}-\mathrm{CaCO}_{3}$ (recharge); $\mathrm{Ca}-\mathrm{Mg}-\mathrm{HCO}_{3} ; \mathrm{Na}-\mathrm{HCO}_{3}$; $\mathrm{Na}-\mathrm{Cl}$ (endmember) [3,28]. While elevated fluoride is expected in geochemically evolved waters, it is commonly found in $\mathrm{Ca}-\mathrm{Mg}-\mathrm{HCO}_{3}$-type where there are basement lithologies [39]. This corresponds with our study area where the dominant water type is $\mathrm{Ca}-\mathrm{Mg}-\mathrm{HCO}_{3}$ and basement lithologies dominate. Figure 4 shows that $\mathrm{Mg}^{2+}$ increases northwest. The loss of $\mathrm{Ca}^{2+}$ for $\mathrm{Mg}^{2+}$ may facilitate the increasing fluoride trend seen in that direction as there is less $\mathrm{Ca}^{2+}$ available to precipitate fluorite $\left(\mathrm{CaF}_{2}\right)$. Groundwater samples from augen gneiss plot closest to equilibrium in Figure 5, indicating that equilibration of fluorite (ultimately controlled by equilibration of calcite) is an active process in those samples.

Regional groundwater flow (northwest) is unlikely to be the dominant process producing the hydrochemical trends in that direction (Figure 4). This is due to the shallow, uneven and seasonally isolated nature of the hydrogeological profile (Figure 3) and low hydraulic conductivity values in those aquifers. Local groundwater flow may, however, have increased influence (albeit minimal) during the wet season where there is higher potential for sub-aquifer connectivity via an elevated water table (Figure 3). The surface of unaltered gneiss beneath the study area is locally uneven, with regolith aquifer thickness ranging from $0-60 \mathrm{~m}$ below the surface. Elongated gneiss mounds 
striking southwest-northeast often breach the surface exposing the uneven nature of the bedrock. These may be potential barriers to groundwater flow. The shallow and uneven nature of the regolith controlled by bedrock surface creates (locally) low sub-aquifer connectivity. These results may reflect a slight dry season-wet season shift in groundwater processes where mostly isolated in-situ weathering of basement rock dominates, with the wet season rains allowing a limited degree of sub-aquifer connectivity, flushing groundwater down-hydraulic gradient from the Nkhoma and Chilenje Hills. This slight seasonal shift in processes was assumed from the available data (locally uneven aquifer thickness and a dry season decrease in groundwater levels) as there were no dry season data to compare. Over time, this may allow some down-hydraulic-gradient geochemical groundwater evolution (i.e., transient development of solute concentrations: Figure 4) to occur in that direction, however, the process would be extremely slow and have a relatively insignificant effect on local groundwater hydrochemistry when compared to in-situ weathering. Augen gneiss hosts the lowest hydraulic conductivities $(\mathrm{K}=0.003-0.046 \mathrm{~m} /$ day) and the outcrop strikes perpendicular to hydraulic gradient, therefore, may act as a boundary to local groundwater flow over lithological boundaries.

Figure 6 confirms rock weathering as the dominant control on fluoride concentrations, with little evaporation or precipitation influence on the hydrochemistry. This supports our hypothesised geological control on groundwater fluoride and significance of in-situ weathering of the underlying geology. Both meta-sedimentary gneiss lithologies play an important role in the concentrations of fluoride that fall within the expected range for rock types [3]. The augen gneiss (alkaline igneous) produced the highest concentrations and is the primary source lithology for fluoride. A geochemical signature for augen gneiss and charnockitic gneiss and granulite appears to be reflected (Figure 4), where low TDS waters (proxy for minimal phreatic influence) from augen gneiss host an order of magnitude higher $\mathrm{Na}^{+}$and $\mathrm{F}^{-}$concentrations than those low TDS waters from charnockitic gneiss and granulite, which may indicate relative parent rock compositional differences (in the absence of rock-powder analyses). These results support the literature consensus that granitic-type rocks host the highest potential for elevated groundwater fluoride [2,15,43]. Augen gneiss outcrops across central Malawi (Figure 2) and may represent a key zone of (dental) fluorosis risk. Hornblende-biotite gneiss on the other hand requires further sampling to be confident in categorising it as a high-risk lithology.

The data support our hypothesis that geology is the dominant control on fluoride occurrence in groundwater in weathered basement aquifers. Weathering of aquifer rock mobilises fluoride into solution, but generally low aquifer transmissivity ensure that fluoride is not transported far from source within the weathered basement profile. This facilitated the development of a map of geological fluoride risk 'zones' (Figure 9). The inherent lack of groundwater fluoride (and other) data for most water points in the study area (and many in Malawi) justifies the need for a preliminary screening approach which can identify high risk zones in the absence of observed groundwater fluoride measurements. User-level risk maps based on Figure 9 could be utilized by local communities to determine if their available, or proposed water points may be at risk from groundwater fluoride. This would be especially useful for users near a zone border who may decide to travel further for water (to a water point within a low-risk zone) to dilute overall fluoride intake. Graded zoning of geological fluoride risk will also prove useful for groundwater development programmes (Government or non-governmental organisations-NGOs) when drilling new boreholes and should be integrated into any subsequent planning strategies. Making informed decisions that avoid drilling in high-risk areas may provide a significant contribution to reducing (dental) fluorosis risk.

\subsection{Human Health Risk}

Our overarching goal is to inform science-led policy change in Malawi to assist the attainment of SDG targets. For a reduction in drinking water fluoride standard from $6 \mathrm{mg} / \mathrm{L}$ to $1.5 \mathrm{mg} / \mathrm{L}$ to be achieved, a direct link (risk) to human health from geologically controlled fluoride must be identified and quantified. The calculation of HQ values was completed for each water point sampled. HQ values provide a specific risk factor for each water point, per age group (Table 3) and support other data, 
identifying augen gneiss as the highest geological fluoride risk lithology (Table 4). HQ values expose the risk from drinking groundwater abstracted directly from high risk lithologies and provide the justification required to advocate policy change. When the HQ values from our sampled water points were compared to the fluoride map contained within the Malawi Hydrogeology Atlas [27], the difference in apparent risk was startling. Malawi's continued use of its $6 \mathrm{mg} / \mathrm{L}$ standard implies that the area is safe from dental fluorosis and (ground) water points within are safe to drink (limited to six water points). The HQ values for the same area are contrary, with $74 \%$ of water points considered unsafe for children aged 6 years old or under to drink, and $44 \%$ of water points unsafe for children under 12 (Table 3).

HQ values have additional value as a means of local risk reduction in the interim. HQ values could be utilised in practice to cycle water use between low and high-risk water points to dilute overall fluoride consumption. For example: anyone over the age of 12 should be safe from developing dental fluorosis by drinking water consistently from water point $30\left(\mathrm{~F}^{-}=0.95 \mathrm{mg} / \mathrm{L}\right)$, but a 6-year-old is vulnerable. Water Point $31\left(\mathrm{~F}^{-}=0.33 \mathrm{mg} / \mathrm{L}\right.$ ), however, is safe for anyone to drink (Table 3). By cycling water intake for children aged 6 years and under (also pregnant and breastfeeding women) between Water Points 30 and 31 (50/50), the overall risk for those vulnerable at Water Point 30 is reduced by half, potentially preventing the development of dental fluorosis in those children. If this method can be applied by users at as many of the vulnerable water points as is possible (recognising variable distances between water points), the incidences of dental fluorosis in the study area could be vastly reduced, preventing potentially thousands of people from developing the condition. This method may prove fruitful in the short term via simple planning and informed decision making at user level.

\section{Policy and Management Implications with Recommendations}

This study began with a challenge: Malawian standard for fluoride in rural (mainly groundwater) drinking water is out of date (currently $6 \mathrm{mg} / \mathrm{L}$ ) and sufficient understanding of fluoride in over 120,000 rural water supplies must be considered within the SDG 6 timeframe. This research was undertaken to support policy change (Figure 10). A science-based understanding of fluoride occurrence in Malawi combining hydro-geochemical, hydrogeological and human health proxy indicator data was used to quantify the geogenic fluoride risk in a case study area where a weathered basement aquifer dominates groundwater quality. We conducted groundwater surveys to assess groundwater fluoride occurrence, household surveys to assess the extent of the human health impact (dental fluorosis) and water point assessments via geospatial geogenic calculations to quantify the risk to human health from naturally occurring fluoride. The outcomes of this research, specifically the direct health link and potential for geological fluoride risk mapping, has instigated a need within the Malawian Government to review a change in the standard and policy for fluoride in rural water supplies, as scaling of the research outcomes can support new standards in line with WHO. We are now working closely with the MoIWD in Malawi to plan a review and assessment of fluoride risks and implementation of an incremental reduction of the fluoride standard, based on the fluoride risk levels identified (Figure 10). 


\section{Challenge}

Groundwater fluoride occurrence in Malawi is geologically-controlled. Some groundwater has fluoride above World Health Organisation guideline values and the Government of Malawi rural groundwater quality standards require science-led policy for reduction from $6 \mathrm{mg} / \mathrm{l}$ to $1.5 \mathrm{mg} / \mathrm{l}$.

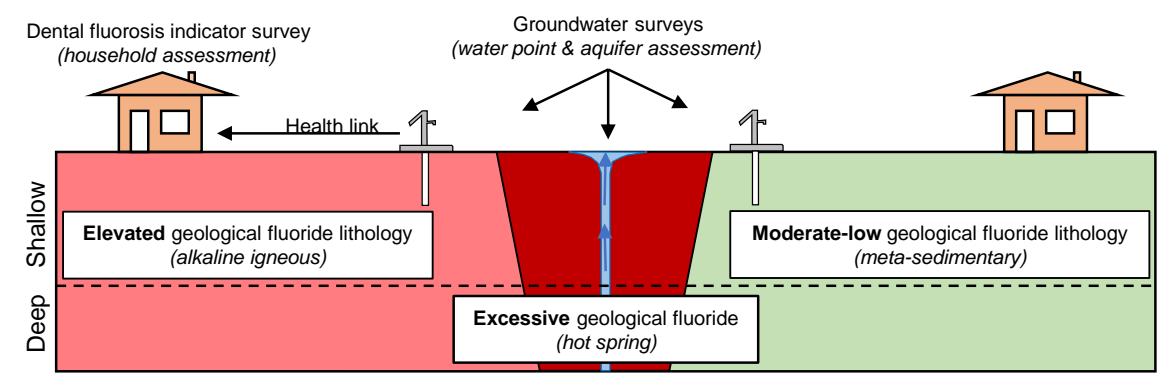

Hydro-geochemical and hydrogeological data combined with human health risk parameters can be used to quantify geogenic fluoride risk in Malawi

\section{Geological Control on Fluoride Occurrence}

Confirmed by field data.

Implications nationally for similar hydrogeological environments.

Facilitates mapping of geological fluoride risk zones.

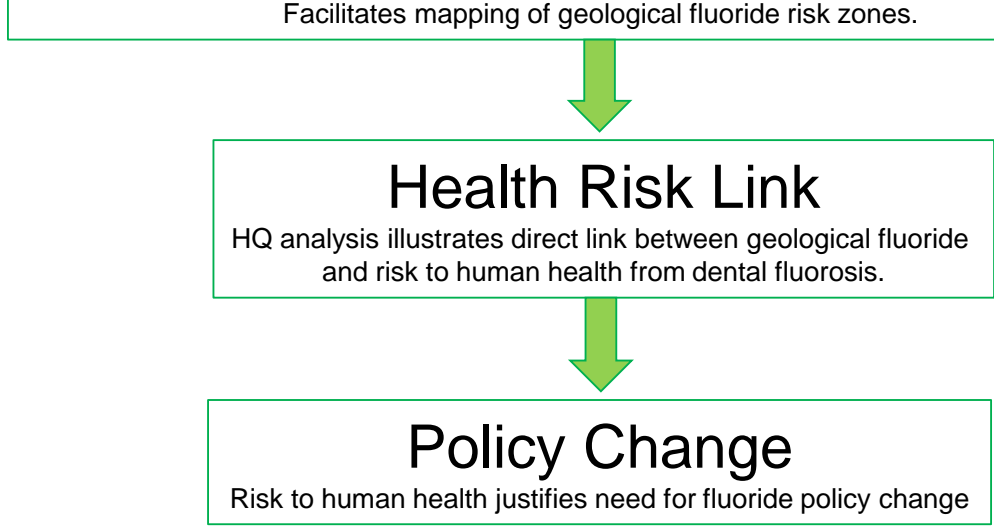

Figure 10. Integrated conceptual model of groundwater fluoride occurrence and health risk linkage leading to advocated groundwater fluoride policy change in Malawi.

This SDG framed research provides tangible and reasonable recommendations which can be implemented within Malawi, including:

- High-level policy change and SDG targets are required for national assessment. Simply changing the fluoride standard from $6 \mathrm{mg} / \mathrm{L}$ to $1.5 \mathrm{mg} / \mathrm{L}$ is unrealistic and expensive. We propose an incremental decrease in the fluoride standard over time. The 1st stage would be a reduction to $4 \mathrm{mg} / \mathrm{L}$ by 2024, instigating an assessment of "excessive fluoride" (hot springs) and "elevated geological fluoride" water points, removing the risk of skeletal fluorosis. Stage 2 would be a reduction to $2 \mathrm{mg} / \mathrm{L}$ by 2028, instigating an assessment of "moderate-low geological fluoride" water points and removing the worst of dental fluorosis risk. The final stage would be a reduction 
to $1.5 \mathrm{mg} / \mathrm{L}$ by 2030, bringing their standard in line with the WHO and removing the remaining risk of dental fluorosis from all water points. An evaluation of individual water points in each stage will identify those most harmful and replacement water supplies must be acquired, highlighting the need for incremental change.

- National geological fluoride risk maps should be developed for Malawi. Statistical analyses of fluoride-lithology relationships where fluoride data exist may be translated into risk maps (similar to Figure 9). For areas where fluoride data do not exist, preliminary risk estimates to be later proven may be extrapolated from existing fluoride-lithology data, justified by literature and applied to similar lithologies on a national scale. Risk maps would ultimately be controlled by a synergy of compositional geology and (fluoride) hydrochemistry in non-rift valley zones, and structural geology, compositional geology, hydrothermal processes, and hydrochemistry in rift valley zones. More complex risk models require extensive data sets which Malawi does not currently possess, therefore, mapping geological risk (i.e., fluoride sources) may be the most achievable method of tackling fluoride occurrence at a national scale. National mapping would allow the Government of Malawi and non-governmental organisations (NGOs) active in the water sector in Malawi to integrate fluoride contamination risk into their groundwater resource development strategies.

- Hazard quotient (HQ) values should be shared locally with water point users. It may prove a simple but effective way to inform local people about the potential dangers of each water point and allow them to make informed decisions about water consumption on their own. Decommissioning water points based on elevated fluoride is an expensive venture as a replacement water supply must be provided. In a country with water scarcity problems and low-income, this is a considerable investment planning issue. Revision of rural water quality standards that allow 'yes/no' information on water quality at the water point and information on the negative health effects of fluoride ingestion may prove much more realistic across the country.

- A wider study of varied lithologies should be sampled in the same manner for hydrochemistry to determine their fluoride-lithology relationships. Both perthitic syenite and limestone (marble in this case) lithologies have been linked to high fluoride and are present in the study area but do not currently have corresponding hydrochemical data. National coverage of lithology types is required.

- Collaboration with dental studies in Malawi would be beneficial to corroborating occurrences of fluoride with definitive and documented incidences of dental fluorosis. This will be achieved by working together at the planning stage to ensure both disciplines are conducting their respective research in the same geographical areas. Sharing of data afterwards and working together on cross-discipline publications would ensure the impact of the research to a wider audience of both scientists and policy makers.

- An investigation into piped water supply networks should be undertaken. Piped groundwater from reticulated wells (high-yielding boreholes) drilled to support a network of pipes, powered by solar panels, to numerous kiosks where users can collect groundwater from the same source should be evaluated for fluoride. If a reticulated well is drilled into augen gneiss where fluoride potential concentrations are high, a larger number of people across a wider area will be at risk. The MoIWD or local government (or NGOs) should test for fluoride at kiosks and if found, water cycling with nearby, low fluoride water points should be advised in the first instance. If such methods are not possible at kiosks, those kiosks should be decommissioned, and replacement water supplies installed. If elevated fluoride is found in numerous kiosks fed from the same well, decommissioning of the full system and replacement of the water supply is advised. Future plans for similar piped supplies should incorporate some level of fluoride risk assessment as described by this study. Simply avoiding target (high geological fluoride risk) lithologies may be enough and should be implemented. 
Supplementary Materials: The following are available online at http:/www.mdpi.com/2076-3417/10/14/5006/ s1, Table S1: summary statistics for fluoride data in the study area, Table S2: geochemical data from TA Mazengera samples.

Author Contributions: Conceptualization, M.J.A.; data curation, M.J.A.; formal analysis, M.J.A.; funding acquisition, R.M.K.; investigation, M.J.A.; methodology, M.J.A.; project administration, R.M.K.; resources, M.J.A., O.P. and W.L.; software, M.J.A.; supervision, M.J.A., M.O.R. and R.M.K.; validation, M.J.A., M.O.R., P.P., P.M., E.M. and M.B.; visualization, M.J.A.; writing—original draft, M.J.A.; writing—review and editing, M.J.A., M.O.R., P.P., P.M., E.M., M.B., O.P., W.L. and R.M.K. All authors have read and agreed to the published version of the manuscript.

Funding: This research was funded by The Scottish Government, via the 'Climate Justice Fund: Water Futures Programme', grant number HN-CJF-03 awarded to the University of Strathclyde (R.M. Kalin).

Acknowledgments: The authors gratefully acknowledge the Scottish Government for funding this research. Further thanks are due to Bawi Consultants for their sampling work during Malawi's wet season, without which this work would not have been possible. The sampling strategy was executed with the utmost care and a high level of precision. Finally, the authors would like to thank the Ministry of Irrigation and Water Development, Malawi for their continued cooperation on this project.

Conflicts of Interest: The authors declare no conflicts of interest. The funders had no role in the design of the study; in the collection, analyses, or interpretation of data; in the writing of the manuscript, or in the decision to publish the results.

Ethical Statement: Regarding the use of the Government of Malawi dental fluorosis indicator data, a number of household, functionality, and water quality surveys were carried out in traditional authority Mazengera by Government and private enumerators over the period of the 2019-2020 financial year. Survey responses were anonymous, and all subjects gave their informed consent for inclusion before they participated in the study which complied fully with the Ethical Guidelines of the Malawi Government. All enumerators were professionally trained on the Malawi Government's ethical guidelines which they ably followed in the field during the surveys.

\section{References}

1. WHO and UNICEF. Progress on Drinking Water, Sanitation and Hygiene: 2017 Update and SDG Baselines; World Health Organization (WHO) and the United Nations Children's Fund (UNICEF): Geneva, Switzerland; New York, NY, USA, 2017; License: CC BY-NC-SA 3.0 IGO.

2. Ozsvath, D.L. Fluoride concentrations in a crystalline bedrock aquifer Marathon County, Wisconsin. Environ. Geol. 2006, 50, 132-138. [CrossRef]

3. Edmunds, W.M.; Smedley, P.L. Fluoride in Natural Waters. In Essentials of Medical Geology Revised Edition; Alloway, B., Centeno, J., Finkelman, R., Fuge, R., Lindh, U., Smedley, P., Selinus, O., Eds.; Springer: Dordrecht, The Netherlands, 2013; pp. 311-350.

4. World Health Organization (WHO). Guidelines for Drinking-Water Quality: Fourth Edition Incorporating the First Addendum; World Health Organization: Geneva, Switzerland, 2017; Licence: CC BY-NC-SA 3.0 IGO.

5. Kalin, R.M.; Mwanamvekha, J.; Coulson, A.B.; Robertson, D.J.C.; Rivett, M.O. Stranded Assets as a Key Concept to Guide Investment Strategies for Sustainable Development Goal 6. Water 2019, 11, 702. [CrossRef]

6. Upton, K.; Ó Dochartaigh, B.; Chunga, B.; Bellwood-Howard, I. Africa groundwater atlas: Hydrogeology of Malawi. Br. Geol. Surv. 2018. Available online: http://earthwise.bgs.ac.uk/index.php/Hydrogeology_ of_Malawi\#: \{\}:text=Malawi\%20is\%20one\%20of\%20the,settled\%20around\%20the\%2010th\%20century (accessed on 1 February 2020).

7. Addison, M.J.; Rivett, M.O.; Robinson, H.; Fraser, A.; Miller, A.V.M.; Phiri, P.; Mleta, P.; Kalin, R.M. Fluoride occurrence in the lower East African Rift System, Southern Malawi. Sci. Total Environ. 2020, 712, 136260. [CrossRef] [PubMed]

8. Ghiglieri, G.; Pittalis, D.; Cerri, G.; Oggiano, G. Hydrogeology and hydrogeochemistry of an alkaline volcanic area: The NE Mt. Meru slope (East African Rift-Northern Tanzania). Hydrol. Earth Syst. Sci. 2012, 16, 529-541. [CrossRef]

9. Nair, K.R.; Manji, F.; Gitonga, J.N. The occurrence and distribution of fluoride in groundwaters of Kenya. Chall. Afr. Hydrol. Water Resour. 1984, 61, 503-512.

10. Olaka, L.A.; Wilke, F.D.H.; Olago, D.O.; Mulch, A.; Musolff, A. Groundwater fluoride enrichment in an active rift setting: Central Kenya. Sci. Total Environ. 2016, 545, 641-653. [CrossRef] [PubMed] 
11. Tekle-Haimanot, R.; Melaku, Z.; Kloos, H.; Reimann, C.; Fantaye, W.; Zerihun, L.; Bjorvatn, K. The geographic distribution of fluoride in surface and groundwater in Ethiopia with an emphasis on the rift valley. Sci. Total Environ. 2006, 367, 182-190. [CrossRef] [PubMed]

12. Msonda, K.W.M. A Study of Groundwater Quality, Defluoridation and Impact of Dental Fluorosis in Children in Nathenje, Lilongwe, Malawi. Master's Thesis, University of Malawi, Zomba, Malawi, 2003.

13. Msonda, K.W.M.; Masamba, W.R.L.; Fabiano, E. A study of groundwater fluoride occurrence in Nathenje, Lilongwe, Malawi. Phys. Chem. Earth 2007, 32, 1178-1184. [CrossRef]

14. Sajidu, S.M.; Masumbu, F.F.F.; Fabiano, E.; Ngongondo, C. Drinking water quality and identification of fluoritic areas in Machinga, Malawi. Malawi J. Sci. Technol. 2007, 8, 42-56.

15. Young, S.M.; Pitawala, A.; Ishiga, H. Factors controlling fluoride contents of groundwater in north-central and northwestern Sri Lanka. Environ. Earth Sci. 2011, 63, 1333-1342. [CrossRef]

16. Nordstrom, D.K.; Jenne, E.A. Fluorite solubility equilibria in selected geothermal waters. Geochim. Cosmochim. 1977, 41, 175-188. [CrossRef]

17. Abdelgawad, A.M.; Watanabe, K.; Takeuchi, S.; Mizuno, T. The origin of fluoride-rich groundwater in Mizunami area, Japan-Mineralogy and geochemistry implications. Eng. Geol. 2009, 108, 76-85. [CrossRef]

18. Naseem, S.; Rafique, T.; Bashir, E.; Bhanger, M.I.; Laghari, A.; Usmani, T.H. Lithological influences on occurrence of high fluoride groundwater in Nagar Parkar area, Thar Desert, Pakistan. Chemosphere 2010, 78, 1313-1321. [CrossRef] [PubMed]

19. Berger, T.; Mathurin, F.A.; Drake, H.; Astrom, M.E. Fluoride abundance and controls in fresh groundwater in Quaternary deposits and bedrock fractures in an area with fluoride-rich granitoid rocks. Sci. Total Environ. 2016, 569, 948-960. [CrossRef]

20. Bennett, A.J.; Barratt, R.S. Some observations on atmospheric fluoride concentrations in Stoke-on-Trent. $R$. Soc. Health J. 1980, 100, 86-89. [CrossRef]

21. Rivett, M.O.; Ellis, P.A.; Mackay, R. Urban groundwater baseflow influence upon inorganic river-water quality: The River Tame headwaters catchment in the City of Birmingham, UK. J. Hydrol. 2011, 400, $206-222$. [CrossRef]

22. Colombani, N.; Di Guiseppe, D.; Kebede, S.; Mastrocicco, M. Assessment of the anthropogenic fluoride export in Addis Ababa urban environment (Ethiopia). J. Geochem. Explor. 2018, 190, 390-399. [CrossRef]

23. Malawi Bureau of Standards (MBS). Drinking Water-Specification; Malawi Standards Board: Blantyre, Malawi, 2005; ICS 13.030.40 MS 214:2005.

24. Carter, G.S.; Bennett, J.D. The Geology and Mineral Resources of Malawi, 2nd ed.; Bulletin No. 6; Government Print: Zomba, Malawi, 1973.

25. Banda, L.C.; Rivett, M.O.; Kalin, R.M.; Zavison, A.S.K.; Phiri, P.; Kelly, L.; Chavula, G.; Kapachika, C.C.; Nkhata, M.; Kamtukule, S.; et al. Water-Isotope Capacity Building and Demonstration in a Developing World Context: Isotopic Baseline and Conceptualization of a Lake Malawi Catchment. Water 2019, 11, 2600. [CrossRef]

26. Climate-data.org. Available online: https://en.climate-data.org/search/?q=nathenje (accessed on 19 June 2020).

27. Malawi Government. Malawi Government. Malawi hydrogeological atlas, 2018. In Ministry of Irrigation and Water Development, Malawi; Government Publication: Lilongwe, Malawi, 2018.

28. Bath, A.H. Hydrochemistry in Groundwater Development: Report on an Advisory Visit to Malawi. British Geological Survey; Report No. WD/05/80/20; British Geological Survey: London, UK, 1980; pp. 29-40.

29. Kirkpatrick, I.M. The Thermal Springs of Malawi. XXIII Int. Geol. Congr. 1969, 19, 111-120.

30. Mkandawire, P.; Chivanga, C. Hydrogeological Reconnaissance Map: Dedza, 1st ed.; Department of Surveys; Malawi Government: Blantyre, Malawi, 1987.

31. Thatcher, E.C. The Geology of the Dedza Area; Geological Survey Department; Bulletin 29; Government Printer: Lilongwe, Malawi, 1969.

32. Leborgne, R. True 2-D Resistivity Imaging from Vertical Electrical Soundings: Application to Groundwater Investigations in Malawi. Master's Thesis, University of Strathclyde, Glasgow, Scotland, 2019.

33. Storey, I. Determination of Transmissivities through Pumping Tests and their Impact on Water Management, TA Mazengera, Malawi. Master's Thesis, University of Strathclyde, Glasgow, Scotland, 2019.

34. Chilton, P.J.; Smith-Carington, A.K. Characteristics of the weathered basement aquifer in Malawi in relation to rural water supplies. Chall. Afr. Hydrol. Water Resour. 1984, 144, 57-72. 
35. Firempong, C.K.; Nsiah, K.; Awunyo-Vitor, D.; Dongsogo, J. Soluble fluoride levels in drinking water-A major risk factor of dental fluorosis among children in Bongo Community of Ghana. Ghana Med J. 2013, 41, 16-23.

36. Adimalla, N.; Rajitha, S. Spatial distribution and seasonal variation in fluoride enrichment in groundwater and its associated human health risk assessment in Telangana State, South India. Hum. Ecol. Risk Assess. 2018, 24, 2119-2132.

37. United States Environment Protection Agency (USEPA): Human Health Risk Assessment. Available online: https://www.epa.gov/risk/human-health-risk-assessment (accessed on 20 December 2019).

38. Qasemi, M.; Afsharnia, M.; Zarei, A.; Farhang, M.; Allahdadi, M. Non-carcinogenic risk assessment to human health due to intake of fluoride in the groundwater in rural areas of Gonabad and Bajestan, Iran: A case study. Hum. Ecol. Risk Assess. 2018, 25, 1222-1233. [CrossRef]

39. Adimalla, N.; Li, P. Occurrence, health risks, and geochemical mechanisms of fluoride and nitrate in groundwater of the rock-dominant semi-arid region, Telangana State, India. Hum. Ecol. Risk Assess. 2018, 25, 81-103. [CrossRef]

40. Du, S.; Liu, Y.; Zhang, L.; Li, H.; Huan, H. Assessment of non-carcinogenic health risks due to water contamination in a loess distribution area, northeastern China. Environ. Earth Sci. 2017, 76, 761. [CrossRef]

41. Yu, R.; Wang, Y.; Ciu, Z.; Xu, G.; Guan, Z.; Yu, Y.; Liu, J. Human health risk assessment of organophosphorus pesticides in maize (Zea mays L.) from Yushu, Northeast China. Hum. Ecol. Risk Assess. 2017, 24, 642-652. [CrossRef]

42. Banerjee, A. Groundwater fluoride contamination: A reappraisal. Geosci. Front. 2015, 6, 277-284. [CrossRef]

43. Sajil Kumar, P.J.; Jegathambal, P.; Nair, S.; James, E.J. Temperature and pH dependent geochemical modelling of fluoride mobilization in the groundwater of a crystalline aquifer in southern India. J. Geochem. Explor. 2015, 156, 1-9. [CrossRef]

(C) 2020 by the authors. Licensee MDPI, Basel, Switzerland. This article is an open access article distributed under the terms and conditions of the Creative Commons Attribution (CC BY) license (http://creativecommons.org/licenses/by/4.0/). 